\title{
Can employee ownership and human resource management policies clash in worker cooperatives? Lessons from a defunct cooperative.
}

\author{
Imanol Basterretxea \\ Department of Financial Economics \\ Faculty of Economics and Business \\ University of the Basque Country UPV-EHU \\ \& Visiting Researcher. Open University \\ imanol.basterretxea@ehu.es \\ Iñaki Heras-Saizarbitoria \\ Department of Management \\ Faculty of Economics and Business \\ University of the Basque Country UPV-EHU \\ iheras@ehu.es \\ Aitziber Lertxundi \\ Department of Financial Economics \\ Faculty of Economics and Business \\ University of the Basque Country UPV-EHU \\ aitziber.lertxundi@ehu eus
}

This is the pre-peer reviewed and pre-copy edited version of the following article:

Basterretxea, I.; Heras-Saizarbitoria, I. and Lertxundi. A. (2019): Can employee ownership and human resource management policies clash in worker cooperatives? Lessons from a defunct cooperative. Human Resource Management, In Press. [DOI: https://doi.org/10.1002/hrm.21957]

The definitive version is available at:

https://rdcu.be/bnPoN

This article may be used for non-commercial purposes in accordance with Wiley Terms and Conditions for Use of Self-Archived Versions." 


\begin{abstract}
The article analyzes the interaction between employee ownership, HRM policies and practices and HRM outcomes in the world's biggest industrial worker cooperative for decades and now defunct Fagor Electrodomésticos. Using longitudinal data and detailed interviews with key stakeholders, this paper sheds light on how employee ownership conditioned HRM policies. HRM outcomes - such as job satisfaction and absenteeism - are also analyzed over a long period of time and for diverse groups in the workforce defined in terms of ownership, age, tenure, salary or professional status. Chronic nepotism when recruiting new members, failures in the training policy, impoverished and Taylorist working systems and reverse dominance hierarchies are analyzed as factors that increased free riding and caused low satisfaction and the disengagement of working members. This case study contributes to the literature on HRM and worker cooperatives as it provides some insights that are rarely found in that literature. It also gives guidance to worker cooperatives about increasing the fit between employee ownership and HRM policies and outcomes.
\end{abstract}

Keywords: Absenteeism; Satisfaction; Employee participation; Conflict; Attitudes: Recruitment; Culture and climate; Worker Cooperatives; Employee Ownership; 
'The form of association, however, which if mankind continues to improve, must be expected in the end to predominate, is not that which can exist between a capitalist as chief, and work-people without a voice in the management, but the association of the labourers themselves on terms of equality, collectively owning the capital with which they carry on their operations, and working under managers elected and removable by themselves'

John Stuart Mill, Principles of Political Economy, 1852 (p. 772).

\section{Introduction}

Collective ownership by employees has been on the agenda of economists, managers, philosophers and policy makers for many years as indicated by the opening citation from English philosopher and political economist John Stuart Mill. The theoretical positive expectations of employee ownership (e.g. Pierce and Furo, 1990; Pierce et al., 1991; Rousseau and Shperling, 2003) and its empirical outcomes (e.g. Hammer et al., 1981; Long, 1982; French and Rosenstein, 1984; Kruse and Blasi, 1995; Kruse, 1996, 2002) have been discussed at some length in the scholarly literature over recent decades. Yet, with few exceptions, little consideration has been given in most of the work to the embeddedness of employee ownership policies within Human Resource Management (HRM). As a result, many research gaps are found. For example, whether, for the success of the shared project, the employee owners should or should not have a substantive 'voice in the management' - to use Mill's words. Or in a similar vein, drawing on the quotation, what would be the real implications of working under managers elected and removable by employees?

A growing number of researchers (Kaarsemaker and Poutsma, 2006; Blasi et al. 2013) have emphasized that the employee ownership perspective should be integrated into a coherent HRM framework. Potential complementarities and clashes between employee ownership and HRM policies and practices such as recruitment, evaluation and compensation need to be researched more deeply. 
Similarly, the employee collective examined in the employee-owned organizations has been viewed as homogeneous, but the characteristics of the 'work-people' involved in the quite diverse experiences of employee ownership are heterogeneous in terms of age, gender, qualifications, rank and stability, and on many other measures (Blasi et al., 2013; Mullins et al., 2016), and those factors have attracted little attention in the scholarly literature.

In order to elucidate these under-researched issues in employee ownership it could be wise to focus on the long-standing and rich experience of fully employee-owned firms such as worker cooperatives. Among the many cooperative experiences in the world, Mondragon is among the most studied (e.g. Sun, 2003; Abrams, 2008). The scattered academic literature on Mondragon cooperatives provides some evidence that some HRM policies and practices can be severely moderated by employee ownership (e.g. Basterretxea and Albizu, 2010; Heras-Saizarbitoria, 2014; Basterretxea and Storey, 2017).

Taking into account the gaps in the literature, this article has two objectives. First, it analyzes potential clashes between ownership and HRM policies and practices in worker cooperatives. Second, it analyzes the effects of employee ownership and HRM practices on HRM outcomes for a heterogeneous workforce in worker cooperatives. To that end, the case of a fully employee-owned firm is studied in depth - the now defunct Fagor Electrodomésticos. Shedding light on the HRM factors and policies that contributed to the demise of Fagor Electrodomésticos provides an opportunity for other companies to learn from their experience and devise strategies to avoid the same fate.

This article contributes to the scholarly literature in several ways. First, the work provides empirical evidence of potential clashes between "fuller" forms of employee ownership and HRM policies and practices. Second, it contributes to filling the gap in the employee ownership literature, where the workforce and its response to ownership has traditionally been viewed as homogeneous. Third, the 
analysis complements the existing literature on worker cooperatives by reporting the reasoning used by different key stake-holders to account for HRM policies and their effect on employee attitudes and behaviors. This helps to explain the cooperative model and its complementarity with other HRM policies. Fourth, it also contributes to the rigorous analysis of HRM policies in relevant cooperative experiences such as Mondragon, which scholars have tended to view in a rather idealized way and previous analysis of management policies has been rather superficial (Heras-Saizarbitoria, 2014).

The paper is organised as follows. The next section reviews the literature related to understanding some HRM specificities in employee-owned firms, with a special focus on the specific case of the fully employee-owned organizations - i.e. cooperatives. The review sheds light on how these factors can contribute to different attitudinal and behavioral responses of heterogeneous workforces. This is followed by an outline of the research methods used in the project reported here, including a brief profile of the case-studied organization. The next section summarizes the results of the field-work. The final section is devoted to discussion and conclusions.

\section{Literature review and research questions}

Empirical studies on the effects of employee ownership on employee attitudes and behaviors increasingly stress the importance of complementing employee ownership with high-performance HRM policies in order to generate higher commitment (Blasi et al. 2008 Kaarsemaker and Poustma, 2006; Kruse et al, 2004, 2010; Kurtulus and Kruse, 2017, among others). Some authors (Kruse et al. 2004, Freeman et al. 2010 and Caramelli, 2011) also stress the importance of developing a corporate culture that combats free-riding to increase commitment in employee owned firms.

While research is increasingly focused on HRM policies that complement employee ownership, additional research is needed to find HRM policies and practices that clash with employee ownership. There is also a need for researching restrictions on HRM managers' action in employee stock ownership (ESO) firms and in cooperatives. The scholarly literature about fully employee 5 
owned organizations, such as of Mondragon's cooperatives, demonstrates that a set of HRM policies and practices may be strongly conditioned by employee ownership. Indeed, employee owners in this type of company have historically opposed many HRM practices, such as individual performance evaluations, pay-for-performance systems, or plans to increase salary differentials to attract and retain senior managers and technicians (Whyte and Whyte, 1988; Kasmir, 1996; Basterretxea and Storey, 2017). Moreover, certain HRM policies and practices that are taken for granted in the tradition of fully employee-owned firms such as cooperatives can run counter to the recommendations of the HRM literature and even clash with them.

The first clash often takes place in the Recruitment and Selection policy. Freedom of HR managers to apply desirable Recruitment and Selection policies and practices can be severely restricted in worker cooperatives. Nepotism and cronyism in recruitment of new members has been frequent in different cooperative firms and other collectivistic organizations, from the Israeli Kibbutz (Van den Berghe, P. L., \& Peter, K,1988), French industrial and agricultural cooperatives (Pasquet and Liarte, 2012; Juban et al. 2015), and Australian consumer co-operatives (Balnave and Paltmore, 2005), to American cooperatives (Rothschild and Whitt, 1989). Cooperatives search for a homogeneous workforce and select a membership that shares basic values and a worldview (Rothschild and Whitt, 1989). Besides value homogeneity, a key alleged reason for nepotistic recruitment policies in worker cooperatives is the so-called "horizon problem" (Borgen, 2004; Jensen and Meckling, 1979). In the absence of freely tradable owner shares, worker owners in a cooperative are not properly motivated to invest, unless they expect to remain in the company for the entire payback term. Mondragon cooperatives have historically overcome this problem by linking cooperatives to a limited geographical environment, "a fact that fosters the informal inheritance of the job" (Arruñada, 1990, 143) and giving preference to descendants of members of the cooperative when recruiting. The policy of hiring descendants of cooperative members solves the horizon problem, but can also have a 
harmful impact on several aspects of people management, including adverse selection, lower job satisfaction, intention to quit, negative word of mouth and job stress (Arasli et al., 2006; Arasli and Tumer, 2008; Ford and McLaughlin, 1986; Sidany and Thornberry, 2013). In addition, nepotism in hiring policies can undermine the basic cooperative principles of Open Membership and Concern for Community.

Restrictions in the Pay policy impose even further limitations on Recruitment and Selection policy in worker cooperatives when firms try to attract valuable and scarce human resources for managerial and technical positions. In fact, limited salary differentials between workers and managers can make it very difficult to recruit managers from Investor Owner Firms (Basterretxea and Albizu, 2011).

HRM policies can be also conditioned by the cooperative "degeneration" process. The academic literature on employee-owned business has been dominated by the "degeneration thesis" (Ben-Ner, 1984; Bonin et al. 1993; Meister, 1984; Miyazaki, 1984; Webb and Webb, 1920). According to this view, cooperatives are bound to fail or to degenerate into capitalist forms of business. The most visible sign of degeneration is directly linked to the recruitment policy: the employment of a growing percentage of wage-laborers instead of members. HRM policies and outcomes can also be influenced by 'organizational degeneration' - a process that increasingly concentrates power and control in managers' hands - and by 'goal degeneration' - cooperatives increasingly prioritizing profits or growth as their prime purpose (Cornforth, 1995).

According to the degeneration literature, worker cooperatives often have a 'life cycle' in which degeneration takes place gradually. In a first stage, idealism and commitment are high, decisions are made in the assembly, but economic activity is poorly established; then, if the cooperative survives, conventional principles of organisation are adopted, indifference substitutes initial idealism and the power of management is reinforced; third, degeneration signs are many, democracy becomes 
restricted to a representative board and goal degeneration takes place; fourth, members and their representatives lose all their power and managers assume total control (Meister, 1984).

Despite the prevalence of the degeneration thesis, many authors (Batstone, 1983; Cornforth, 1995; Estrin and Jones, 1992; Hernandez, 2006; Storey et al., 2014) have argued that cooperative degeneration is not inevitable; cooperatives can also regenerate.

Far from concentrating power and control in a few oligarchic hands as the degeneration thesis predicts, some cooperatives can develop a "reverse dominance hierarchy", a kind of hierarchy in which "followers dominate their leaders rather than vice versa" (Boehm, 1993, 228). Cooperatives developing a reverse dominance hierarchy would be characterized by a "presence of largely powerless chiefs" and a formal "managerial structure that does not translate into the exertion of much power and authority by chiefs over subordinated workers" (Jaumier, 2017, 221). This particular hierarchy can restrict managers' action and limit their choice when it comes to applying certain HRM policies, even if these are seen as being more effective. Limitations on decision-making can also extend to middle-management and supervisors (Basterretxea and Storey, 2017).

Reverse dominance hierarchy in worker cooperatives may partially explain the historical difficulty of implementing individual performance evaluations and performance-based remuneration in some Mondragon cooperatives (Whyte and Whyte, 1988; Kasmir, 1996; Basterretxea and Storey, 2017). Difficulties in implementing performance evaluation and performance related pay can increase the risk of "free-riding", a problem that can be a major source of negative attitudinal and behavioral outcomes in employee-owned companies (Bonin et al 1993; Klein, 1987; Kruse et al. 2004; McCarthy et al. 2010; Pendleton and Robinson, 2010; Basterretxea and Storey, 2017).

Given that most researchers consider that employee ownership only produces positive attitudinal and behavioral responses if embedded in bundles of high performance HRM practices (Blasi et al., 2008; 
Caramelli, 2011; Kruse et al., 2010), and considering that potential clashes between HRM practices and employee ownership are under-studied, the following research question is formulated:

Research question 1: How does employee ownership in worker cooperatives condition HRM policies and practices and the achievement of better HRM outcomes?

To the best of our knowledge, only the paper by Klein and Hall (1988) considers a wide range of factors that make it possible to know how different workforces respond to employee ownership. According to their findings, satisfaction is positively related to individual characteristics such as age, salary, and tenure, but negatively related to level of education. They also suggested that these characteristics could be moderated by organizational factors. In this regard, age could be a significant determinant in companies in which employees have to wait until their retirement to recover their initial investment. Pendleton (2005) found evidence that age, orientation towards participating in stock ownership and portfolio diversification have a positive effect on stock-holding behavior. Contrary to his expectations, income and risk preferences had little effect on stock-holding. Ownership status has also been analysed. Using data from a number of different satisfaction surveys conducted in Mondragon's retail cooperative, Eroski, Arando et al (2015) and Basterretxea and Storey (2017) found that cooperative working members were less satisfied than workers with partial ownership through an ESO plan. Similarly, they were less satisfied than employees who had no ownership rights. Basterretxea and Storey (2017) also found higher absenteeism rates among working owners in the cooperative. Raised but unfilled expectations of participation are mentioned in both studies as a cause of negative HRM outcomes. Almost 100\% employment security, an egalitarian pay policy and worsening pay and labor conditions during the crisis were also found to be factors that promoted complacency and free riding of some members (Basterretxea and Storey, 2017). 
Attitudes towards employee ownership are worse among lower paid and economically insecure workers, given the extra risk that employee ownership implies to the income of partners (Blasi et al. 2010); and among those with less business literacy (Comeau, 1993, Kasmir, 1996). In her analysis of Fagor, Kasmir (1996) found a stronger sense of ownership and stronger feeling of being part of the firm among technicians and managers than among rank and file cooperative workers.

Instead of analyzing responses of employee owners as a whole, it is important to analyze the different responses of employees according to different workforce characteristics. Therefore, the following research question is proposed:

Research question 2: How do attitudinal and behavioral responses of employee owners in a working cooperative differ depending on different workforce characteristics (e.g. employment status, age, employee rank)?

We address the research questions by studying the case of Fagor Electrodomésticos, S.Coop..

\section{Fagor Electrodomésticos S.Coop.: Summary Profile}

A brief historical review of Fagor Electrodomésticos S.Coop (hereafter referred to as Fagor) is given in Molina (2012) and Errasti et al. (2016), but the key points are summarized here.

Before its decline and eventual closure in November 2013, Fagor had been the flagship of the Mondragon Cooperative Group, one of the largest industrial groups in Spain. At the height of its success in the household appliance industry in 2006, it was a multinational with 18 production plants in six countries ( 8 in Spain, 4 in France, 1 in Poland, 1 in Italy, 3 in China and 1 in Morocco), sales of 1,729 million euro, $6 \%$ of the European market and a workforce of 10,543 employees. Fagor was created in 1956 with a culture that emphasised the values of solidarity, self-sacrifice, democracy, concern for the welfare of the community and an organization in which the sovereignty of labour prevailed over capital (Molina, 2012). After a successful period in the Spanish market, in the late 
1980s it began an international expansion into North Africa and Latin America. Between 1996 and 2001, it made major investments in its Spanish plants and entered a number of joint ventures with leading international firms. In 1999 Fagor bought the Polish white goods company Wrozamet. In 2005, it bought Brandt Electroménager, the French leader in household appliances. At one point it was the fifth largest manufacturer of household appliances in Europe after Electrolux, Whirpool, Bosch Siemens and Merloni (Molina, 2012). As happens with other Mondragon cooperatives, cooperative ownership was not offered to the employees of the foreign subsidiaries that Fagor acquired. In addition, close to $15 \%$ of the worforce in the parent company were temporary employees who had no ownership rights.

\section{(Insert Table 1 about here)}

The acquisition of Brandt was to mark a turning point in Fagor's history (Ortega and Uriarte, 2015). Because of difficulty accessing the capital market, the company financed its internal and external growth strategies through borrowing, with a negative effect on its books. When the financial crisis broke in 2008, the property market in Spain collapsed (in 2007 close to 700,000 new houses were built, but in 2013 and 2014 around 74,000 and 45,000 were built, respectively), together with the market for domestic appliances in Spain, the firm's most important market. Fagor's already difficult situation was further worsened by the emergence of new Asian competitors, leading to a sharp decline in Fagor's sales and margins. Measures such as liquidity injection by the Mondragon Corporation, staff relocations to other Mondragon cooperatives, early retirement and reductions in advances and salaries, were not enough to stave off bankruptcy proceedings.

\section{Methods}


The research was based on field-work based mainly on qualitative data obtained through in-depth interviews with a set of representative and reliable internal and external stakeholders of Fagor. Complementary to this, very extensive internal and external (public) corporate data related to Fagor over extended periods of time were analyzed.

Regarding the qualitative analysis, 25 interviews were conducted with a cross section of people involved with the cooperative in a variety of roles in order to try to increase the richness and the reliability of the information (Miles and Huberman 1994). Referencing and snowball sampling were used to define a sample of stakeholders to interview. These included 12 senior executives ( 3 of them also representatives of the Governing Council and 2 of them also members of the Social Council for different periods of time), 6 rank and file worker owners, including 3 leading representatives of the Social Council for the last 25 years of the firm, a senior union official who defended non-owner employees during the bankruptcy process, 3 senior managers in Mondragon central offices, and 4 senior Basque Government officials responsible for industrial policy. Most of the former managers and rank and file workers who were interviewed had been working for Fagor for at least two decades and in many cases had quite conflicting and contending perspectives. External stakeholders who were interviewed had also been closely associated with Fagor and Mondragon Corporation for long periods of time.

The interviews were conducted between October 2015 and September 2017, after the collapse of the company. This phase of data collection was stopped at the point of saturation (Eisenhardt, 1989; Francis et al., 2010). Interviews focused on the choices and events that, in the view of the interviewees, were critical to explain the demise of the company. In order to gain the participants' trust and avoid organizational silence, social desirability and other similar bias such as the potential tendency of the interviewees to approach the interviews cathartically (Heras-Saizarbitoria, 2014), the solely scholarly aim of the research, the diversity of the background of the respondents, the 
respondents' anonymity and the confidentiality of all information obtained were guaranteed. All interviews were recorded and professionally transcribed.

A grounded theory method of interpretation was used for data analysis, an inductive analytical method with great potential for this type of research (Strauss and Corbin, 1990). According to this approach, data interpretation must be based on a set of categories that emerge from the study. The iterative process of data categorization and interpretation was conducted by the three authors. This process applied to the semi-structured interviews made it possible to identify passages that illustrate the main themes (i.e. drivers for the failure of Fagor) emerging from the category analysis.

Regarding the more relevant external (public) data, this paper draws extensively on secondary sources such as annual reports, official reports and the Bankruptcy Report, written by the insolvency administrator. With regard to the internal data, many internal reports on HRM outcomes for extended periods of time were analyzed. More specifically, the results of the three last satisfaction surveys conducted by Fagor Electrodomésticos in 2003, 2005 and 2008 and longitudinal monthly data on absenteeism for the different business units from 1995 to 2013 were analyzed. We also had access to several internal in depth analyses of absence management conducted by Fagor's HRM department between 2005 and 2010. Those documents analysed the causes of sick leave rates for different workforce segments and proposed measures to the Governing Council and to the General Assembly to reduce voluntary absenteeism. It was not possible to conduct regressions because the microdata of those surveys were not available. The firm no longer exists, and much data has been destroyed or mislaid. The satisfaction surveys and the analyses of absenteeism in Fagor were not collected for academic research purposes, and results are not presented in a way that allows the derivation of further descriptive statistics. Yet some weakness on the data is compensated for, since longitudinal data collected by HR managers in Fagor comes from a large sample of employees that would be almost impossible to achieve if the data set was collected by outside researchers. 
The validity of factors was supported by the use of diverse sources of information and the internal validity was guaranteed by the search for common patterns that explain the phenomena. The information gathered from the interviews was triangulated with the quantitative information from the desk research. Having access to knowledgeable informants with long term relationships with the firm, and longitudinal quantitative data, offered the possibility to gain rich insights. For example, in order to analyze the effect of employee ownership on HRM outcomes, key data of satisfaction and absenteeism surveys were presented to the interviewees, who were asked to tell their version of "the story behind the numbers". Since satisfaction and absenteeism surveys showed various results for different segments of the workforce identified in terms of employment status, age, rank, and so on, we interrogated the different stakeholders about their own interpretations of those differences and the ways they made sense of the data. Different points of view were surfaced and tested, by feeding back the accounts of interviewees (unascribed) to others and asking them to comment. Throughout this historical account, interviewees were asked questions about particular decisions and processes in the company, and critical external events, and how these affected the demise of the company. These included perceptions of the company's strengths and weaknesses in HRM policies.

\section{Results}

\section{Clashes between employee ownership in Fagor and recruitment and selection policy: perverse nepotism}

According to almost all our informants, rather than attracting better workers, lower-quality workers were more likely to join Fagor Electodomésticos in basic blue collar positions due to what Padgett et al. (2015) describe as "bad nepotism". Other Mondragon cooperatives have applied nepotistic recruitment policies, combining them appropriately with criteria of meritocracy and implementing guidelines and boundaries in the sense proposed by Bellow (2003) and Laker and Williams (2003). Fagor, on the other hand, gave preference to the offspring of members without requiring most of 
them to meet any minimum educational standards. Interviewees classed this policy of nepotistic recruitment and selection as "unsuitable", "a problem"; "a fatal error", "a perverse policy", "the absolute evil", "a terrible social mistake", "a disaster", "a cancer", and so on. Only two of the twenty-five interviewees (one member of the Social Council and a trade union representative) played down the gravity of nepotistic selection policies.

Specific details of this policy are given below. The last regulation on selection of new members at the Fagor Group, comprising eight working cooperatives, was published on 23 May 2002. Under these rules, up to 30 points out of a possible 100 were awarded for having a parent who was a member. This compares to just 10 points for having more than 5 years' work experience and 16 points extra for having higher-level secondary education, as opposed to having no educational qualifications whatsoever.

This recruitment policy led to adverse selection in terms of skills and attitudes. Most interviewees also said that many members used this nepotistic policy to favour their offspring with poorer training, skills and attitudes:

"If you have a child who's not very bright, you send them to the cooperative. Why? Obviously, a bright child will find work elsewhere (...). That happened a lot in Mondragon. (...) If you're required to take in the children of members with no qualifications, then the worst tends to happen. Members' children make less effort too. They know they're going to be made members at the end of the trial period. They're not motivated and they don't value hard work.” (Fagor manager)

Some interviewees justified the low level of qualifications required of new members in a Taylorist production model like that at Fagor Electrodomésticos: "You don't need to be Einstein to put screws into a washing machine. There were plenty of people at Fagor Electrodomésticos who had no training because it wasn't needed" (Fagor manager). For this reason, most interviewees felt that the 
lack of engagement and commitment seen among many members' children joining the company was more important than their lack of educational qualification.

According to the interviewees, managers at Fagor and the HR department tried repeatedly to increase the requirements for membership. Employee ownership conditioned the adoption of boundaries and all change proposals failed because of the opposition of worker owners in the Social Council and the General Assembly:

"At one General Assembly, we discussed a proposal from the personnel staff that all new members, including direct labour, regardless of the score for being members' children, should sit an aptitude test and have an interview to screen them in some way. But the General Assembly voted against the move. That was what Fagor was like from a social point of view" (Fagor manager)

Now, with the benefit of hindsight and given the gravity of the outcome, even some of those who defended nepotistic recruitment policies on the Social Council and argued against any change recognise that the policy was a serious social and business error:

“The entry of member's children was a terrible social error (...) We've created a serious problem of 'in-breeding' in the cooperatives (...); we scored them based on the parent's seniority and demanded very little in terms of educational qualifications. So, all kinds of people joined the company, including people who really didn't perform, people who didn't even pass the trial period. (...). It was a social error, and it was mistake on our (the Social Council's) part to have defended that sort of thing [emphatically]." (Member of Fagor's Social Council)

Even if managers blame the Social Council and rank and file cooperative members in the General Assembly for maintaining a "bad nepotism" recruitment policy, it could also be argued that it was management's fault for not taking the lead and convincing cooperative members of the need for a 16 
change. In many other Mondragon cooperatives managers in the early 1990s had had the leadership and pedagogical skills to convince opposing cooperative members of the need to establish minimum training requirements (vocational training degrees) for all new cooperative members and instituting filters in the recruitment process to avoid recruiting new members with poor attitudes.

According to some of the interviewees, another reason for this lax and misguided policy on recruiting member's children was the limitation the cooperative faced in financing expansion and the need to ensure that members did not withdraw their capital from Fagor after they retired. Under the rules for new Fagor Group members, children of retired members enjoyed the same status as children of active members, provided the parents retained their economic stake in the company (Fagor, 2002; Norma de selección de ingresos 23/5/2002, p.10).

Clashes between employee ownership and the recruitment and selection policy can be specially hard when the worker cooperative is recruiting large numbers of new members. Whyte and Whyte (1988) and Kasmir (1996) report that many previous worker-manager conflicts in Fagor took place after periods when the membership had expanded rapidly and there had been insufficient time to induct and train members and introduce them to the meaning of cooperativism. According to our informants, the growth of Fagor and the need to replace many retiring cooperative members forced the company to hire close to 1,000 new members between 1997 and 2003. Some years, up to 300 new members were hired in a single recruitment round, making it impossible to transmit the cooperative and corporate culture to new entrants:

"It was like a tsunami. In just one year, it's difficult to assimilate 300 new members aged between 18 and 20, people who've dropped out of school because what they want is money and a 9-to-5 job. You put them all together, with their own culture and their vision (...). And there's nobody by their side to instil our previous culture of effort and commitment to them. (...). There's no one left, they've all gone” (Fagor manager) 
As in previous rapid expansions of Fagor reported by Rothchild and Whitt (1986), this mass influx of 1,000 new members seems to have eroded the cultural values of previous generations, resulting in a cultural shift in which the balance between the cooperative members' rights and obligations was lost:

"There was a very clear change in culture from the mid-90s on. Many of members' children came in with low educational qualifications and they viewed being a cooperative member as being something like a civil servant. 'I've got job security, no one's ever going to fire me. I can say whatever I feel like. I have plenty of rights but I don't think I have any obligations, or at least not many'. That has been the prevailing culture in recent years, especially among younger people.” (Fagor manager)

\section{Attitudinal and behavioral responses to employee ownership and HRM policies among different workforce segments in Fagor}

According to the interviewees, the induction of many new young cooperative members with little training and poor attitudes towards work and cooperative values was the main reason for a worsening in the HRM outcomes, such as absenteeism, between the mid-1990s and the demise of the company in 2013.

While the first researchers of the 'Mondragon Experience' reported that absenteeism rates of cooperative members were about half those in comparable local firms (Bradley and Gelb, 1981; Thomas and Logan, 1982), absenteeism rates of cooperative working members in Fagor were a constant cause for concern for HR managers in its final two decades.

Absenteeism rates had been below 4\% until 1995, but doubled in a decade as shown in Figure 1.

\section{(Insert Figure 1 about here)}

The long term increase in sick leave rates over the 1995-2013 period did not have obvious medical reasons. The company had invested millions in new factories, production lines and processes that 
improved ergonomics and safety in the workplace, thus reducing the risk of accidents, injuries and sickness due to the work conditions. In addition, the average age of cooperative members went down in this period, from 45.5 in 1999 to 43 in 2006 (Fagor 2006), something that theoretically should have contributed to lower absenteeism rates.

We could only gather comparative data of absenteeism rates for different ownership status in the parent company for 2010 (an absenteeism rate of $3.37 \%$ for non owners compared with $8.8 \%$ for working owners) and for 2013 (1.02\% and 6.28\% respectively). Former managers in the HR department confirmed that absenteeism rates were higher for cooperative members than for non members in the long term and that deterioration in commitment began as soon as the candidates were converted into cooperative owners. According to the interviewees, a greater sense of job security underlies those results, as in the researches of Blasi et al. (2008) and Basterretxea and Storey (2017):

"The moment they became members, their sense of commitment just slipped away. (...), Being a member was almost like being in the public service. Absenteeism sky-rocketed, especially on Mondays. I think it was a lack of commitment. And I think Human Resources should have come down harder on them." (Fagor manager)

As Figure 2 shows, the number of days of sick leave per 100 employees were much higher than the average in more than 100 Mondragon cooperatives and also much higher than the number considered to be normal by the HR department of Fagor (0.33 sick absences/employee/year $\left.{ }^{1}\right)$.

\section{(Insert Figure 2 about here)}

As in the case of Eroski (Basterretxea and Storey, 2017), internal analyses of absenteeism in Fagor show that when cooperative members get sick, they stay at home longer than the average employee 
in Spanish firms for similar sickness (see Figure 3), which is interpreted as a sign of low commitment.

\section{(Insert Figure 3 about here)}

Absenteeism rates differed from some business units to others, with some reaching two digit sick leave rates in many years, as Lavavajillas (13.81\% absence for sickness in 2010) and Lavadoras (12.51\% in 2010). Managers argued that different cultures where developed in different business units. In smaller business units a culture of mutual control made it easier to fight against free riding and voluntary absenteeism in the sense proposed by Kruse et al (2004). Conversely, in large business units where there was massive recruitment of new members in the late 1990s and early 2000s, a more complacent corporate culture made shirking easier.

Internal analyses on the causes of absenteeism conducted by the HR managers of Fagor over the years, and also the opinions gathered in our interviews, consider that absenteeism rates reflected a lack of responsible engagement and involvement with the cooperative project of many members, especially the younger blue collar working members:

“Absenteeism among young people was two or three points higher than among older people who theoretically should have more health issues. (...) Absenteeism was concentrated to a great extent in direct labour and especially among the young. We concluded that there was a lower degree of engagement." (Fagor manager)

In 2005, the company conducted an analysis of absenteeism. It showed that $45 \%$ of all sick leave was being taken by the 18- to 35-year olds, who represented roughly $30 \%$ of the members. They accounted for $47.69 \%$ of all short-term sick-leave (1 to 3 days), where it was difficult for the company's medical services to check the validity of the claims. It can be deduced that this included most of the voluntary absenteeism. The report said that "our organization is sick" and estimated the cost of absenteeism at Fagor at €9,585,958 for 2005 alone $-€ 2,396,489$ in direct costs and 20 
$€ 7,189,469$ in indirect costs (training substitutes, productivity losses, material losses, hours lost due to reorganization of selection processes, reorganization of the line and reduced quality). In March 2007, at an Extraordinary General Assembly, the HR department warned of an "alarming rise in absenteeism which could create economic and social difficulties for the firm and threaten the whole Fagor Electrodomésticos business project." They called for "this major problem to be solved".

The analysis "Absentismo 2010: Estado de Situación y Planes de Acción" reported even higher rates than in 2005 , showing that high absenteeism had become chronic.

\section{(Insert Figure 4 about here)}

The increase in the absenteeism rate of working owners in 2009 and 2010 took place at a time when cooperative members took many austerity measures to face the crisis, including reducing their salaries and being relocated to other companies. Those measures created many social tensions and disputes, and, as in the case of Eroski (Basterretxea and Storey 2017), interviewees considered that increased absenteeism rates in 2009 and 2010 can be partially interpreted as a "silent response" of some cooperative owners to austerity measures.

Apart from age, gender was also a topic of internal absenteeism analysis at Fagor, where women had on average 1.7 sick absences per year compared with 1.0 for men, according to the 2005 internal study. According to our interviewees, those gender differences were stable over time. In addition to the effect of maternity leave, interviewees and internal analyses conducted by the firm suggest the importance of women's "double presence at work and at home" and also the fact that women were proportionally more likely to be in the least skilled positions where possibilities of sick absence were higher because of the monotony and repetitive nature of the tasks. The same reason explains why absenteeism was much higher among blue collar workers and in some business units and factories.

Attitudinal responses measured in different satisfaction surveys conducted by Fagor are consistent with the behavioral responses. We had access to the results of the three last satisfaction surveys 
conducted in 2003 (based on the responses of 2,910 employees out of 4,124), 2005 (2,417 out of 4,148), and 2008 (1,859 out of 2,918). As Figure 5 shows, the business units with higher absenteeism rates are the ones with lower satisfaction rates (Pearson correlation -0.899 , significant at the 0.01 level (bilateral)).

\section{(Insert Figure 5 about here)}

In addition to the differences in culture mentioned above, different characteristics of employees working in different business units also explain disparities in satisfaction and absenteeism. As Figure 6 shows, satisfaction of direct labor seems to be lower than that of indirect labor.

\section{(Insert Figure 6 about here)}

The satisfaction survey of 2003 offers even more fine grained results for different workforce segments (depending on age, tenure, income, training, and professional status) allowing a greater understanding of the differential effect of employee ownership on different groups.

\section{(Insert Table 2 about here)}

There seems to be evidence of an increasing trend of global satisfaction as age; tenure; training and salary and professional rank increases. However, the significance of differences cannot be formally assessed as the individual data are not available.

As with the absenteeism results, age, salary and tenure seem to be positively associated to satisfaction. Satisfaction of younger cooperative members seems to be lower than that of older members, which could be interpreted as further evidence of the failure in the nepotistic recruitment policy and also a flaw in the training and transmission of cooperative and corporate culture to young millennials.

Similarly, tenure and salary seem to be positively associated with satisfaction, supporting the previous study on ESOP companies conducted by Klein and Hall (1988). Unlike that study, however, 
it would appear that in Fagor training might be also positively related to satisfaction. In fact, cooperative worker owners with a university degree were more satisfied than those with a vocational training degree or with only primary education. Vocational training made no difference.

Interviewees linked higher satisfaction of indirect labor and higher rank and more educated members with absenteeism results of different business units. In fact, those business units with lower absenteeism rates (external organization and central services) are the units with more indirect labor, a higher percentage of university graduates and members in higher positions.

Higher satisfaction of indirect labor and higher rank members would be consistent with previous studies on Fagor that found a stronger sense of ownership and stronger feeling of being part of the firm among technicians and managers than among rank and file cooperative workers (Kasmir, 1996, 161-163).

Recruitment and training policies explain to a great extent a higher satisfaction and commitment of higher rank members with university studies. As in other Mondragon cooperatives, recruitment for skilled technicians and university graduates was enhanced by the preferential recruitment of candidates coming from corporate training centers such as Mondragon University (Basterretxea and Albizu, 2011). Those corporate training centers produce candidates who are more familiar with cooperative culture and have a more favorable attitude toward joining a cooperative enterprise. Also, the recruitment and selection processes for technical and management positions took subjective indicators into account to ascertain if candidates shared basic cooperative values.

As mentioned above, small differences in salaries between workers and managers, difficulty adapting to cooperative values and the continuous and critical internal control by cooperative worker owners in the Governing Council and General Assembly, made it very difficult to recruit managers from Investor Owner Firms. Those limitations made Fagor and other Mondragon cooperatives consider 
technicians and managers as scarce and valuable strategic human capital, providing these members with extensive training (both technical and cooperative) and internal promotion opportunities.

While lower rank members complained about the training policy in the satisfaction surveys, most of our informants considered that huge training opportunities were offered to working members but most members (especially those with lower training levels) were reluctant to follow training programs:

“People didn't see any need for training. The Social Council frequently complained that no training was being generated from the cooperative. We organised various programmes for training personnel in welding and modules but we just made fools of ourselves; people didn't want to do it and no one signed up. And in the Social Council itself, they stopped bringing up the issue because the evidence spoke for itself." (Fagor manager)

Reluctance of cooperative members who lacked vocational training to receive training was also referred to by the four senior Basque Government officials responsible for industrial policy interviewed. All of them emphasized that when the company collapsed, public efforts to help redundant cooperative members receive formal vocational training to increase their employability where received with negative attitudes of many members and their representatives in the Social Council.

\section{Cooperative degeneration versus a reverse dominance hierarchy conditioning HRM policies}

For more than five decades Fagor was able to overcome the darkest prognostications of the cooperative degeneration thesis. Not only was the company profitable in the long term, but it maintained a large proportion of members in its workforce. As Table 1 shows, before the acquisition of the French firm Brandt in 2005, more than $60 \%$ of the workforce were still cooperative members. While Basque law allowed it to have up to $25 \%$ of wage labourers in the parent cooperative company, interviewees highlight that Fagor usually had a lower percentage of wage labourers, as a 
sign of commitment to cooperative values and also due to the pressure of the Social Council. Seeing the failure of Fagor with hindsight, twenty four out of the twenty five interviewees consider that the only thing that could (perhaps) have saved Fagor commercially was a much more rapid and drastic cooperative degeneration. Instead of investing heavily in its Spanish factories in the late 1990s and early 2000s, the company should have followed the delocalization path of other European competitors, progressively closing its less efficient factories in Spain and substituting expensive worker partners with cheaper hired wage-labourers in its Polish factory or in other cheap labor countries. Such a move, all interviewees agree, would have been impossible given the cooperative nature of Fagor and the impossibility of working owners voting in favour of firing themselves to hire cheaper wage-labourers. Instead of 'goal degeneration', most interviewees highlight that Fagor prioritized for too long the goal of maintaining cooperative jobs in the parent company, even if this goal was against profitability.

Nor did the threatened "organizational degeneration" take place, according to our interviewees. In fact, instead of power and control being increasingly concentrated in a few oligarchic hands, interviewees describe the existence of a reverse dominance hierarchy.

As reported by our interviewees, relationships between staff and management deteriorated to a great extent into an us-and-them acrimony, making it difficult to implement hard HRM decisions to turn around the vicious spiral into which the company had fallen.

Many of the HR policies at Fagor seem to have been influenced by historical social conflicts between grass roots worker members and managers at the cooperative. Some of these conflicts persisted in the firm's collective memory, conditioning HR policies for decades. While other smaller cooperatives have reduced shirking and complacent attitudes of some members, adopting performance evaluation and salary systems that penalize poor performers and shirking members, those kind of pay sanctions were not implemented at Fagor. When asked why, many of the interviewees referred to past social 
conflicts, such as the strike of 1974. On that occasion, the management at Fagor tried to introduce job assessment systems. These would have allowed managers to make a subjective appraisal of the members working under them, evaluating certain qualitative variables such as work quality, responsibility, attitude toward others and cooperation. The strike of cooperative workers was over the system of evaluation and strikers insisted on the retention of egalitarian pay and abandoning supervisors' discretionary role in rating individual workers. In subsequent decades, this would lead to a culture of remuneration based on egalitarianism, and little connection between pay and performance. Similar opposition of worker owners to pay for performance systems have been found in other big Mondragon cooperatives, such as Eroski (Basterretxea and Storey, 2017).

Other social conflicts at the firm also ended with the defeat of proposals from management and the Governing Council at various General Assemblies. On several occasions, this resulted in mass resignations from the Governing Council or resignation or dismissal of the CEO and other senior executives. In May 1992 the Governing Council resigned en masse, led by chairman Javier Salaberria, when it failed to push through a proposal to modify executive pay (from a pay differential ratio of $1: 3$ to $1: 6)$ at the General Assembly. Some interviewees also alluded to this resignation and the conflict that arose over executive remuneration between worker members and executive members as one of factors that conditioned the company's wage policies over subsequent decades. In 2006, CEO Pablo Mongelos proposed cutting salaries and performing extraordinary solidarity (unpaid) hours to tackle the crisis. His proposals were defeated at the General Assembly. After pressure from the Social Council, Mongelos was dismissed and the entire Governing Council and some members of senior management subsequently resigned. Most of the interviewees identified this dismissal of executives proposing tough and unpopular HR policies as a major turning point which helps explain the subsequent failure of Fagor. Adoption and implementation of later cutbacks was hindered and delayed by the power of the Social Council and a fear among management that the Social Council and the General Assembly might reject their proposals and that they might eventually be dismissed 26 
like Mongelos. Measures that some interviewees believe might have avoided the complete collapse of the company - such as closure and transfer of highly loss-making units to low-cost countries were not even raised, as executives were convinced they would be rejected by the General Assembly. When middle managers saw that the top managers' priority was social peacekeeping and that they were afraid of the Social Council and General Assembly, the managerial capability of middlemanagement and their capacity for influence amongst their teams was also reduced. Faced with problems of indiscipline, suspicion of voluntary absenteeism, low performance of some members or decisions to bring in new members, middle management did not feel they had the support of their superiors or of the HR Department. As in the case of another fully owned organization from Mondragon, Eroski (Basterretxea and Storey, 2017), this prompted many supervisors to shirk their monitoring tasks, adopting a laissez-faire leadership style in order to avoid conflicts with shirking members or even with descendants of members who aspired to become members, despite their low skills and poor attitudes.

"As a manager, if you issued an unfavourable report after a candidate member's trial period and the Social Council defended the candidature, your judgement would be called into question. You would be called into question and crucified, [emphatically] crucified. (...) Many managers, the majority, backed down.

Three years before the firm closed, all middle-managers attended a course. The instructor told us; "The managers at Fagor are neither authoritarian nor participative; you are relinquishers. You relinquish your function, but you don't relinquish your salaries. That's the sort of managers you are”. That's what he said. And he was spot on! That relinquishing style of control extended to all the executives (...). But like it or not, we had no option if we wanted to survive." (Fagor manager) 
The reverse dominance hierarchy made sanctioning shirking members extremely difficult. As an example, economic penalties and sanctions imposed on members taking too many sick leaves slightly reduced sick leave rates between 2006 and 2008, but absenteeism went up again when sanctions of absent members were reduced or refunded because of the pressure from the Social Council.

\section{Clashes between employee ownership and rigid Taylorist production systems}

Since the early 1970s the executives at Fagor were concerned with the internal contradiction between the democratic cooperative system of government and the rigidity of the Taylorist profiles in the way labor relations were handled (Molina, 2006). They decided to promote new, more effective, ways of organising labor in some divisions that would be in harmony with cooperative values. Nevertheless, according to some of the interviewees, the best way to operate many production units in the white goods industry is still on the Taylorist-Fordist system. Taylorist production systems are considered to be incompatible with the participation and autonomy of cooperative workers (Kurtulus and Kruse, 2017) something that was stressed by some interviewees.

"If someone is working eight hours a day on a production line... in structural terms, the work itself is a very important limiting factor. If you work on a production line, then you're living in an environment of passive labour. You're told what to do... You don't have the capacity to change things. You have a lower level of commitment and satisfaction. (...) If your job, your working environment, doesn't match what you're being sold (autonomy, participation, etc.), it doesn't work..." (Mondragon senior manager)

Those opinions are in line with previous research conducted in Fagor in the 1990s by Kasmir, who found that employee owners working in the assembly line felt they were treated as "chickens in a coop" (Kasmir, 1996, 187), exploited “just like any worker in any firm” (Kasmir, 1999, 386). 
As well as lack of motivation, some interviewees said that members who feel alienated on Taylorist assembly lines tend to use their vote on cooperative management bodies like alienated workers rather than as worker-employers:

"I think it's counterproductive to have members on the assembly line performing a repetitive job eight hours a day. In those circumstances, however much ownership they may have, the reality of their day-to-day existence is a "nightmare". (...) To add to it, those people have a vote, and they're the majority... So of course, that majority behaves as if they were in an investor-owned firm (...), but they have a vote. (...) In certain companies, cooperativising certain jobs is not a good idea, because it hinders competitiveness. Fagor Electrodomésticos was one of those cases.” (Mondragon senior manager)

Employee involvement and participation in day-to-day decisions is extremely limited when working on an assembly line; training is unnecessary to conduct repetitive and simple tasks and the path of the chain exerts an automatic supervision and control over the employee. In fact, in the 2003, 2005 and 2008 satisfaction surveys, some of the least valued items are "Participation in the work area", "Professional development in the job" and "Training" (see Table 2). Evaluations of those items are especially weak among cooperative workers of lower professional rank and training level. Raised and unfulfilled participation expectations among rank and file employee owners is, therefore, interpreted as a cause of dissatisfaction, in line with previous research (Arando et al. 2015; Basterretxea and Storey, 2017; Ben-Ner and Jones, 1995; Klein and Hall, 1988; Kruse and Blasi, 1995; McCarthy et al. 2010).

Some production units, such as "Cooking", organized workplace production systems and decisionmaking in ways to get more employee input and involvement (e.g. with a basis of a participative TQM approach). After the mid-1990s, Cooking changed the layout of the factory, adopting u-shaped production cells that required a higher polyvalence of workers. Accordingly, all satisfaction surveys 
we had access to, show higher satisfaction of workers in Cooking than in Taylorist production units, such as Frío.

Other units of Fagor failed to conduct similar organizational changes, sometimes because of the opposition of cooperative working members, as in the case of Fagor Clima (Kasmir, 1996). In other cases (according to our interviewees) it was because of mismanagement and inability to replicate good practices, and in yet others it was because of the firm belief that the Taylorist model was the best for some production units.

\section{Discussion and Conclusions}

The present paper enhances our understanding of the relationships between fully employee-owned organizations (i.e. worker cooperatives), and HRM policies and outcomes in many ways.

Our findings in Fagor suggest that age, tenure, salary, professional rank, and education were positively associated with a higher satisfaction. Behavioral responses might also differ in line with attitudinal responses, with more sick absences among younger worker owners and among direct labor. Women would appear to have higher absenteeism rates, mainly because of their higher representation in lower rank jobs. Given the relative different mix of worker characteristics in Fagor's different business units, satisfaction and absenteeism rates differ between them. Similarly, different results in previous empirical research on the effect of employee ownership on employee attitudes and behaviors could have been caused by different compositions of the workforces in the firms that were studied.

Our findings also enrich the existing literature, pointing out that employee ownership in worker cooperatives can clash with different HR policies. HR managers in mainly or fully employee-owned companies can face many limitations that make the implementation of high-performance HRM policies, or even standard HRM policies, very difficult. 
Our research findings show that a major clash can happen between employee ownership in worker cooperatives and some individual HRM policies, such as recruitment and selection, performance evaluation, performance related pay and absence management. In the case of Fagor, the wrong people were recruited and selected due to a nepotistic recruitment policy, with the selection of the offspring of members with no training and poor working attitudes. Massive recruitment of close to 1,000 new members, mostly descendants of members with little training and poor working attitudes, between the mid-1990s and 2003, provoked a significant drop in member commitment, according to interviewees. Those opinions were backed by satisfaction surveys and by rising absenteeism rates, most obviously among younger members. As our analysis shows, despite different efforts by the HRM department to change the recruitment policy and establish higher training requirements and more professional screening processes to evaluate the involvement and commitment of candidates to cooperative and corporate culture, employee owners opposed those changes repeatedly through the General Assembly and Social Council.

While our study focuses on the case of Fagor Electrodomésticos, some of the clashes between employee ownership and HR policies documented here have also been documented in other large Mondragon cooperatives, such as Eroski (Basterretxea and Storey, 2017). Similarly, some of the forces that fostered nepotism in recruitment policies of this cooperative (free riding problems, financing problems, horizon problems) are common to other worker cooperatives. In fact, the regulation on selection of new members that promoted nepotism in Fagor Electrodomésticos was a regulation shared with seven other Mondragon cooperatives (Copreci, Arrasate, Automation, Ederlan, Electronica, Industrial and Mondragon Assembly). Further research is needed in order to evaluate how nepotistic policies have affected HR outcomes in other Mondragon cooperatives.

HR departments of worker cooperatives should make an effort to avoid "bad" nepotism policies and implement guidelines and boundaries to the nepotism policies in order to reduce their negative 
effects. Efforts will have to be made in the communication and creation of a culture that makes nepotism recruitment policies compatible with meritocratic criteria.

Many of the negative HRM outcomes of Fagor were caused because of its size and previous rapid expansion of membership and because of the substitution of large numbers of retiring members by younger members. The massive induction of new young members impeded the maintenance and nurturing of the pre-existing cooperative and corporate culture. Some of our informants suggested that other Mondragon cooperatives that actually are very successful, such as Fagor-Ederlan, are also increasing their membership too fast and may face negative HRM outcomes in the future as happened in Fagor. Successful worker cooperatives in other regional settings, or worker cooperatives facing the substitution of a high percentage of their older and retiring members, should also be aware of the risks of rapid and massive recruitment. While many academics conceive the failure to transmit cooperative culture to new entrants as a training policy problem, the managers we interviewed consider this interpretation rather naïve. Formal cooperative training has been provided by Fagor and all Mondragon cooperatives to new entrants for years (Basterretxea and Albizu, 2010), but those programs have limited effects in changing attitudes, values and behaviors. Informal transmission of cooperative and corporate culture by members with longer tenure to newcomers is much more important. But such informal transmission is difficult when 1,000 new cooperative workers enter a firm in a few years, as happened in Fagor between 1996 and 2003, and many old members are retiring in the same period. Difficulties were exacerbated in some business units where generational replacement was more extreme. Other worker cooperatives facing similar growth or generational replacement needs, should consider the importance of securing the informal transmission of the organizational culture. Besides hiring new members, relocating older members from some business units to others can be necessary to ensure that all business units have a minimum percentage of long 
tenured employee owners who can transmit the organizational employee-ownership culture to newcomers informally.

Fagor's case is also an instructive lesson for many investor-owned firms that wish to foster ESO. Those companies operating in industries where rigid Taylorist production systems still offer the most productive way of working should think twice before promoting employee ownership plans to all their workforce. When production systems prevent significant participation of the employee in dayto-day operational decisions and working life, offering ownership rights to employees can increase their expectations of participation, expectations that inevitably will be frustrated and denied by the reality of their daily working experience.

For those worker cooperatives that already have such a disjunction between their Taylorist production systems and the participation and autonomy fostered by the cooperative model, some of our informants proposed some good examples of other Mondragon cooperatives, that in the past had conventional Taylorist production systems with low training requirements, and have changed their production system to get a higher congruence with cooperative values and be able to achieve cooperative advantages. Those changes have required more automation of production processes and reducing the workforce dramatically, but the remaining worker owners are highly qualified, with more responsibility and enriched tasks, which fits better with the autonomy and participation that the cooperative model fosters.

Our findings show that a set of HRM policies rooted in the cooperative nature of Fagor exacerbated the problems of the company and made the turnaround significantly more difficult. Many of the former managers and workers of Fagor we have interviewed are actually relocated to other Mondragon cooperatives. This provides them the opportunity to see whether other cooperatives have learnt the lessons of Fagor's failure. When it comes to HRM lessons, most interviewees note that other cooperatives are now much more cautious in their recruitment and selection policies. 
Educational requirements of potential new members have been raised and subjective evaluations of candidates' work ethic and involvement with cooperative values are now much more important.

A key to understanding all the HRM problems in Fagor and the persistent inability of management to solve them may be the impoverished managerial capabilities of managers at all levels, due to a reverse dominance hierarchy. Working and managing associations of laborers 'under managers elected and removable by themselves' - as Mill predicted would be the norm if mankind improved seems to be a really complex issue. In his Principles Mill himself referred to a set of 'admirable qualities' by which the pioneering worker owned organizations maintained workers in increasing prosperity: 'Their rules of discipline, instead of being more lax, are stricter than those of ordinary workshops; but being rules self-imposed, for the manifest good of the community, and not for the convenience of an employer regarded as having an opposite interest, they are far more scrupulously obeyed, and the voluntary obedience carries with it a sense of personal worth and dignity' (Mill, 1987; p. 778). It might be wise to reflect on the present prevalence of another conflict of interests: the opposite interest between the convenience of some employees and the 'manifest good of the community'. This conflict seems hard to manage in worker cooperatives in the modern society in which they are embedded. This is particularly the case in large organizations, where the 'selfimposition' is more easily watered down.

\section{Limitations and avenues for further research}

The main limitations of this study are those inherent in the qualitative methodology used and the type of company analyzed. As stated, methodological precautions were considered in the field-work to limit potential biases, such as a the tendency to minimize suggestions of managerial failures by interviewed managers, and the potential inclination to give self-indulgent opinions by memberworkers. Yet those and other similar biases could have affected some outcomes. 
Fagor was the biggest industrial cooperative of the Mondragon experience, and many results can be useful for other big fully employee-owned companies. Nevertheless, the generalization of these results to other cooperatives and other types of ESO firms should be treated with caution.

As Jaumier (2017) suggests, reverse dominance hierarchies and subsequently weakened leadership of managers may be more widespread among worker cooperatives than suggested by the current state of the literature. Further research is needed to analyze the possible presence of reverse dominance hierarchies in ESO firms where the majority of shares and votes are on the hands of workers. Similarly, the effect of employee ownership on HRM outcomes for different segments of the workforce will also have to be studied in different kinds of employee owned firms operating in other industries and countries.

\section{References}

Abrams, J. (2008). Companies we keep: Employee ownership and the business of community and place. Chelsea Green Publishing.

Arando, S., Gago, M., Jones, D. C., \& Kato, T. (2015). Efficiency in Employee-owned enterprises: an econometric case study of Mondragon. ILR Review, 68(2), 398-425.

Arasli, H., Bavik, A. \& Erdogan H. E. (2006). The effects of nepotism on human resource management. The case of three, four and five star hotels in Northern Cyprus. International Journal of Sociology and Social Policy, 26 (7/8), 295 - 308.

Arasli, H., \& Tumer, M. (2008). Nepotism, favoritism and cronyism: A study of their effects on job stressand job satisfaction in the banking industry of north Cyprus. Social Behavior and Personality: An international journal, 36, 1237-1250..

Arruñada, B. (1990). Economía de la empresa: un enfoque contractual. Ariel. 
Basterretxea, I. \& Albizu, E. (2010). ¿Es posible resistir a la crisis? Un análisis desde la gestión de las políticas de formación y empleo en Mondragón, CIRIEC España. 67. 75-96.

Basterretxea, I. \& Albizu, E. (2011). Management Training as a Source of Perceived Competitive Advantage: The Mondragon Cooperative Group Case, Economic and Industrial Democracy, 32(2), 199-222.

Basterretxea, I., \& Storey, J. (2017). Do Employee-Owned Firms Produce More Positive Employee Behavioural Outcomes? If Not Why Not? A British-Spanish Comparative Analysis. British Journal of Industrial Relations. DOI: 10.1111/bjir.12247

Balnave, N., \& Patmore, G. (2005). Rochdale consumer co-operatives and Australian labour history. In The Past is Before Us, Ninth Proceedings of the Ninth National Labour History Conference (pp. 3-10).

Bellow, A. (2003). In Praise of Nepotism: A Natural History. New York: Doubleday.

Ben-Ner, A. (1984) 'On the Stability of the Cooperative Type of Organization', Journal of Comparative Economics 8(3): 247-60.

Ben-Ner, A. \& Jones, D. C. (1995). Employee participation, ownership, and productivity: a theoretical framework. Industrial Relations: A Journal of Economy and Society, 34(4), 532-54.

Blasi, J. R., Kruse, D. L., \& Markowitz, H. M. (2010). Risk and lack of diversification under employee ownership and shared capitalism. In D. In Kruse, R. Freeman \& J. Blasi (Eds.). Shared Capitalism at Work: Employee Ownership, Profit and Gain Sharing, and Broad-based Stock Options (pp. 105-136). Chicago: University of Chicago Press.

Blasi, J.R., Freeman, R.B., Mackin, C. \& Kruse, D.L. (2008). Creating a bigger pie? The effects of employee ownership, profit sharing, and stock options on workplace performance. Working Paper 14230, National Bureau of Economic Research, Cambridge, MA, August. 
Blasi, J., Freeman, R., \& Kruse, D. (2013). The Citizen's Share: Reducing Inequality in the 21st Century. Yale University Press.

Boehm, C., (1993). Egalitarian behavior and reverse dominance hierarchy. Current Anthropology, $34(3), 227-254$.

Bonin, J. P., Jones, D. C. \& Putterman, L. (1993) Theoretical and Empirical Studies of Producer Cooperatives: Will Ever the Twain Meet?, Journal of Economic Literature 31(3), 1290-320.

Borgen, S. O. (2004). Rethinking incentive problems in cooperative organizations. The Journal of Socio-Economics, 33(4), 383-393.

Bradley, K \& Gelb, A. (1987). Cooperative labor relations. Mondragon response to recession. British Journal of Industrial Relations. 25 (1). 77-97.

Bretos, I., \& Marcuello, C. (2017). Revisiting Globalization Challenges and Opportunities in the Development of Cooperatives. Annals of Public and Cooperative Economics, 88(1), 47-73.

Caramelli, M. (2011). Towards a Theory of the Attitudinal Effects of Employee Stock Ownership. Paper presented at the The Beyster Simposium. December 8-11. Rutgers University.

Comeau, Y. (1993). Bilans de satisfaction dans les coopératives de travail québécoises. Nouvelles pratiques sociales, 6(2), 141-153.

Cornforth, C. (1995) 'Patterns of Cooperative Management: Beyond the Degeneration Thesis', Economic and Industrial Democracy 16(4): 487-523.

Eisenhardt, K.M. (1989). Building Theories from Case Study Research. Academy of Management Review, 14(4), 532-550. 
Errasti, A., Bretos, I., \& Etxezarreta, E. (2016). What Do Mondragon Coopitalist Multinationals Look Like? The Rise and Fall Of Fagor Electrodomesticos S. Coop. And its European Subsidiaries. Annals of Public and Cooperative Economics, 87(3), 433-456.

Estrin, S. and Jones, D. C. (1992) 'The Viability of Employee-Owned Firms: Evidence from France', Industrial and Labor Relations Review 45(2): 323-38.

Ford, R., \& McLaughlin, F. (1986). Nepotism: boon or bane. Personnel Administrator, 31(11), 7889.

Francis, J. J., Johnston, M., Robertson, C., Glidewell, L., Entwistle, V. Eccles, M. P., \& Grimshaw, J. M. (2010). What is an adequate sample size? Operationalizing data saturation for theory-based interview studies. Psychology and Health, 25, 1229-1245.

Freeman, R.B., Blasi, J.R. \& Kruse, D.L. (2010). Introduction. In D.L. Kruse, R.B. Freeman, \& J.R. Blasi (Eds.), Shared Capitalism at Work: Employee Ownership, Profit and Gain Sharing, and Broad-based Stock Options, (pp. 1-37). Chicago: University of Chicago Press.

French, J. L., \& Rosenstein, J. (1984). Employee ownership work attitudes, and power relationships. Academy of Management Journal, 27(4), 861-869.

Hammer, T. H., Landau, J. C. \& Stern, R. N. (1981). Absenteeism when workers have a voice: The case of employee ownership. Journal of Applied Psychology, 66(5), 561.

Heras-Saizarbitoria, I. (2014). The ties that bind? Exploring the basic principles of worker-owned organizations in practice. Organization, 21(5), 645-665.

Hernandez, S. (2006) 'Striving for Control: Democracy and Oligarchy at a Mexican Cooperative', Economic and Industrial Democracy 27(1): 105-35.

Jaumier, S. (2017). Preventing chiefs from being chiefs: An ethnography of a co-operative sheetmetal factory. Organization, 24(2), 218-239. 
Jensen, M. C., \& Meckling, W. H. (1979). Rights and production functions: An application to labormanaged firms and codetermination. Journal of Business, 52 (4), 469-506.

Juban, J. Y., Charmettant, H. \& Magne, N. (2015). Les enjeux cruciaux du recrutement pour les organisations hybrides: les enseignements à tirer d'une étude sur les Scop. Management \& Avenir, (8), 81-101.

Kaarsemaker, E. C. \& Poutsma, E. (2006). The fit of employee ownership with other human resource management practices: theoretical and empirical suggestions regarding the existence of an ownership high-performance work system. Economic and Industrial Democracy, 27(4), 669-85.

Kasmir, S. (1996). The myth of Mondragon: Cooperatives, politics, and working class life in a Basque town. Albany, State University of New York Press.

Kasmir, S. (1999). The Mondragon model as post-Fordist discourse: Considerations on the production of post-Fordism. Critique of Anthropology, 19(4), 379-400.

Klein, K. J., \& Hall, R. J. (1988). Correlates of employee satisfaction with stock ownership: Who likes an ESOP most? Journal of Applied Psychology, 73(4), 630.

Klein, K. J. (1987). Employee stock ownership and employee attitudes: A test of three models. Journal of Applied Psychology, 72(2), 319.

Kruse, D. (1996). Why do firms adopt profit-sharing and employee ownership plans?. British Journal of Industrial Relations, 34(4), 515-538.

Kruse, D., Freeman, R., Blasi, J., Buchele, R., Scharf, A., Rodgers, L., \& Mackin, C. (2004). Motivating employee-owners in ESOP firms: Human resource policies and company performance. Advances in the Economic Analysis of Participatory and Labor-Managed Firms, 8, 101-127.

Kruse, D. (2002). Research evidence on prevalence and effects of employee ownership. Journal of Employee Ownership Law and Finance, 14(4), 65-90. 
Kruse, D., \& Blasi, J. (1995). Employee ownership, employee attitudes, and firm performance (No. w5277). National Bureau of Economic Research, Cambrige, MA.

Kruse, D. L.; Freeman. R. B.; Blasi, J. (2010) Shared Capitalism at Work: Employee Ownership, Profit and Gain Sharing, and Broad-Based Stock Options. University of Chicago Press.

Kurtulus, F. A. \& Kruse, D. L. (2017). How Did Employee Ownership Firms Weather the Last Two Recessions?: Employee Ownership, Employment Stability, and Firm Survival: 1999-2011. Kalamazoo, MI: W.E. Upjohn Institute.

Laker, D.r. \& Williams, M.L. (2003). Nepotism's effect on employee satisfaction and organisational commitment: an empirical study. Int. J. of Human Resources Development and Management, 3(3), 191-202.

Long, R. J. (1982). Worker ownership and job attitudes: A field study. Industrial Relations: A Journal of Economy and Society, 21(2), 196-215.

McCarthy, D., Reeves, E., \& Turner, T. (2010). Can employee share-ownership improve employee attitudes and behaviour? Employee Relations, 32(4), 382-395.

Meister, A. (1984) Participation, Associations, Development, and Change. New Brunswick, NJ: Transaction Publishers.

Miles, M.B. \& Huberman, A.M. (1994). Qualitative data analysis: An expanded sourcebook. Thousand Oaks, CA: Sage.

Mill J.S. (1852)., Principles of Political Economy. Rist. A. Kelley, Fairfield, NJ, 1987.

Molina, F. (2006) Fagor Electrodomésticos (1956-2006): historia de una experiencia cooperativa. Mondragón: Fagor Electrodomésticos. 
Molina, F. (2012). Fagor Electrodomésticos: The multinationalisation of a Basque co-operative, 1955-2010. Business History, 54(6), 945-963.

Mullins, F., Weltmann, D., Blasi, J. \& Kruse, D. (2016). Employee Stock Ownership for Managing Human Resources. Call for Papers HRM Special Issue, Human Resource Management.

Miyazaki, H. (1984) 'On Success and Dissolution of the Labor-Managed Firm in the Capitalist Economy', Journal of Political Economy 92(5): 909-31.

Ortega, I. \& Uriarte, L. (2015). Retos y dilemas del cooperativismo de Mondragon tras la crisis de Fagor Electrodomésticos. Cuadernos de Lanki, 10.

Padgett, M.Y., Padgett, R.J. \& Morris, K.A. (2015). Perceptions of Nepotism Beneficiaries: The Hidden Price of Using a Family Connection to Obtain a Job, Journal of Business Psychology, 30, $283-298$

Pasquet, P., \& Liarte, S. (2012). La Société Coopérative et Participative: Outil de gestion pour l'entrepreneur social ou une nouvelle hypocrisie managériale?. RIMHE: Revue Interdisciplinaire Management, Homme \& Entreprise, (3), 3-16.

Pendleton, A. (2005). Sellers or keepers? Stock retentions in stock option plans. Human Resource Management, 44(3), 319-336.

Pendleton, A. \& Robinson, A. (2010). Employee stock ownership, involvement, and productivity: an interaction-based approach. Industrial and LaborRelationsReview, 64(1), 3-29.

Pierce, J. L. \& Furo, C. A. (1990). Employee ownership: Implications for management. Organizational Dynamics, 18(3), 32-43.

Pierce, J. L., Rubenfeld, S. A., \& Morgan, S. (1991). Employee ownership: a conceptual model of process and effects. Academy of Management Review, 16, 121-144. 
Rothschild, J., \& Whitt, J. A. (1989). The cooperative workplace: Potentials and dilemmas of organisational democracy and participation. CUP Archive.

Rousseau, D. M. \& Shperling, Z. (2003). Pieces of the action: Ownership and the changing employment relationship. Academy of Management Review, 28(4), 553-570.

Sidany, Y.M. \& Thornberry, Y.M. (2013). Nepotism in the Arab World: An Institutional Theory Perspective. Business Ethics Quarterly, 23(1), 69-96.

Strauss, A.L \& Corbin, J.M. (1990). Basics of qualitative research: grounded theory procedures and techniques. Sage. Newbury Park, Ca.

Storey, J., Basterretxea, I., \& Salaman, G. (2014). Managing and resisting 'degeneration'in employee-owned businesses: A comparative study of two large retailers in Spain and the United Kingdom. Organization, 21(5), 626-644.

Sun, L. (2003). Ownership and governance of enterprises: Recent innovative developments. Springer.

Thomas, H. \& Logan, C. (1982). Mondragon: An Economic Analysis. London: Allen \& Unwin.

Van den Berghe, P. L., \& Peter, K. (1988). Hutterites and kibbutzniks: A tale of nepotistic communism. Man, 23 (3), 522-539.

Webb, S. and Webb, B. (1920) A Constitution for the Socialist Commonwealth of Great Britain. London: Longman.

Whyte, W.F. \& Whyte, K.K. (1988). Making Mondragon. Ithaca, NY: ILR Press. 
Figure 1: Sick leave rates* of Fagor Electrodomésticos cooperative working members 1995-2013

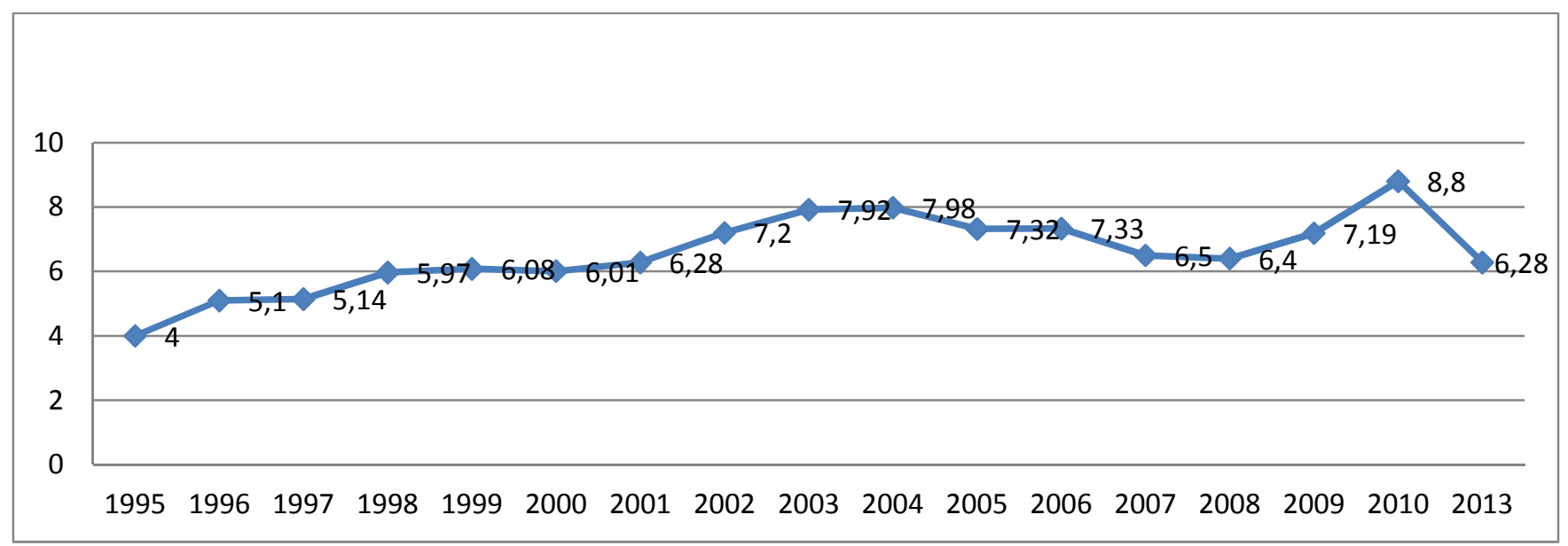

*Sick leave rates $=\%$ of sick and accident leave hours / total working hours. Data for 2011 and 2012 was not available.

Source: Data gathered from the company.

Figure 2: Sick absence processes per 100 coop working members

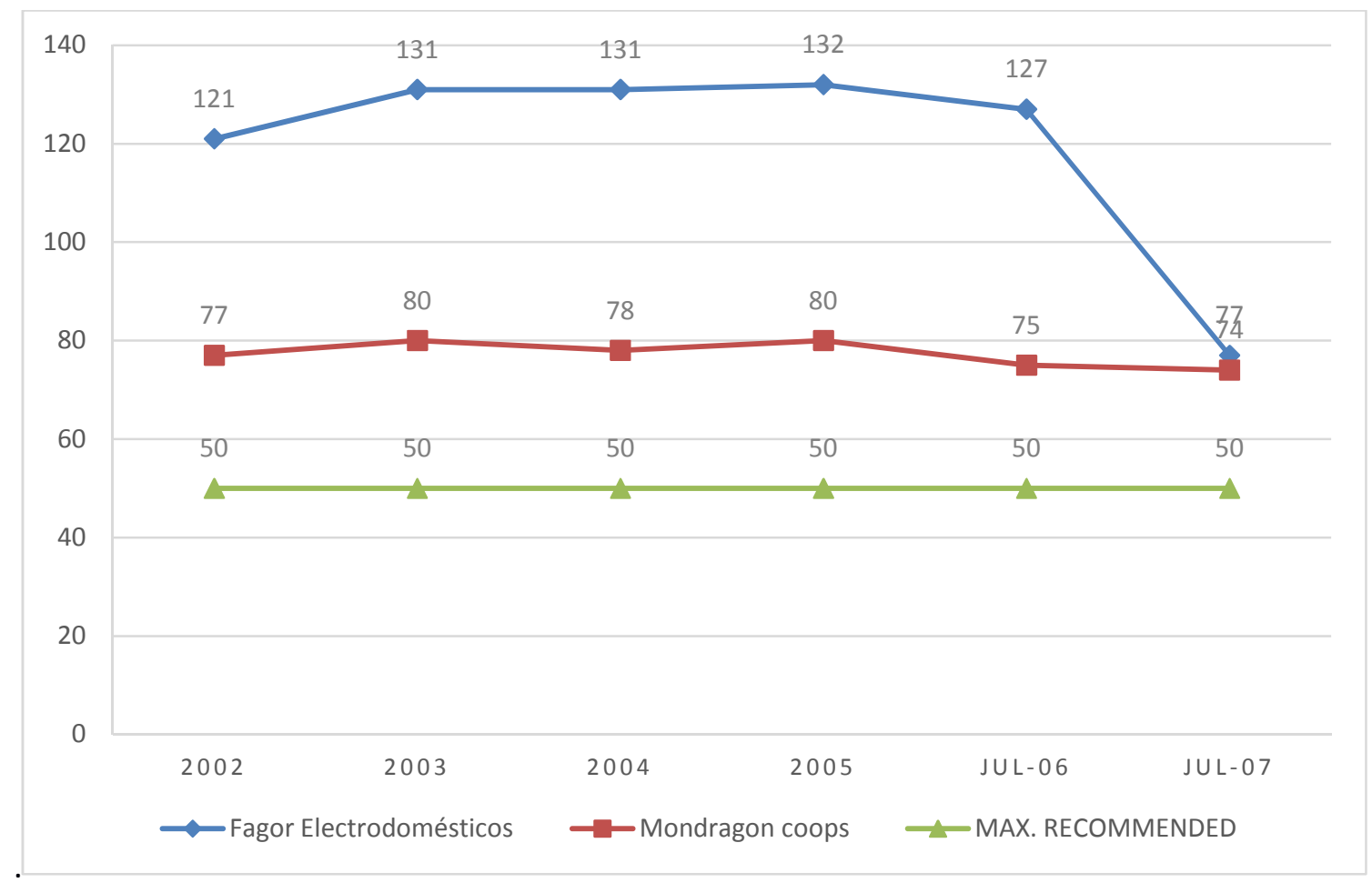


Figure 3: Duration of sick absence processes in Fagor compared to Mondragon cooperatives and Spanish firms in 2005

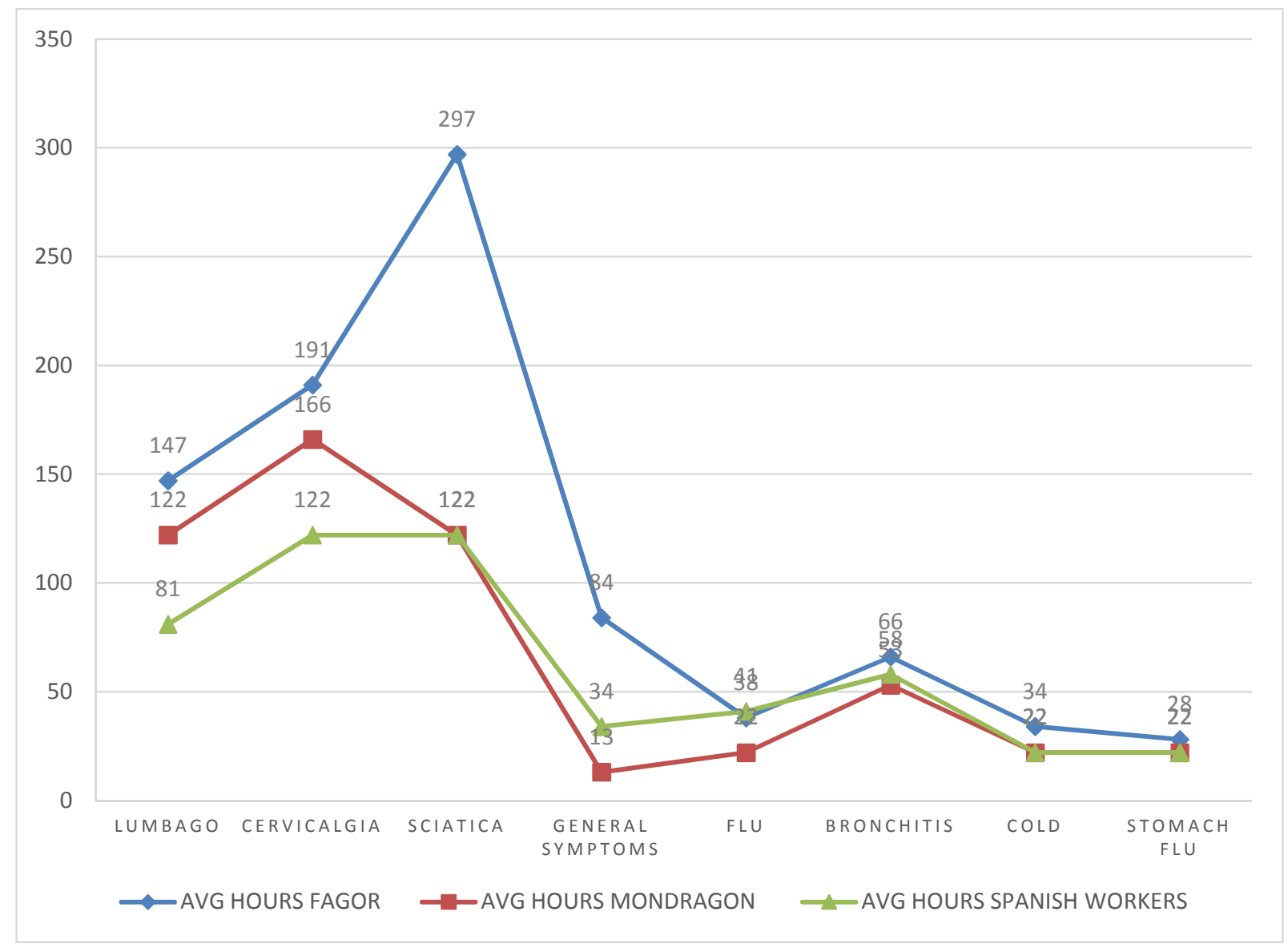

Source: Data gathered from the company.

Figure 4: Percentage of total sick absences in relation to the age brackets 


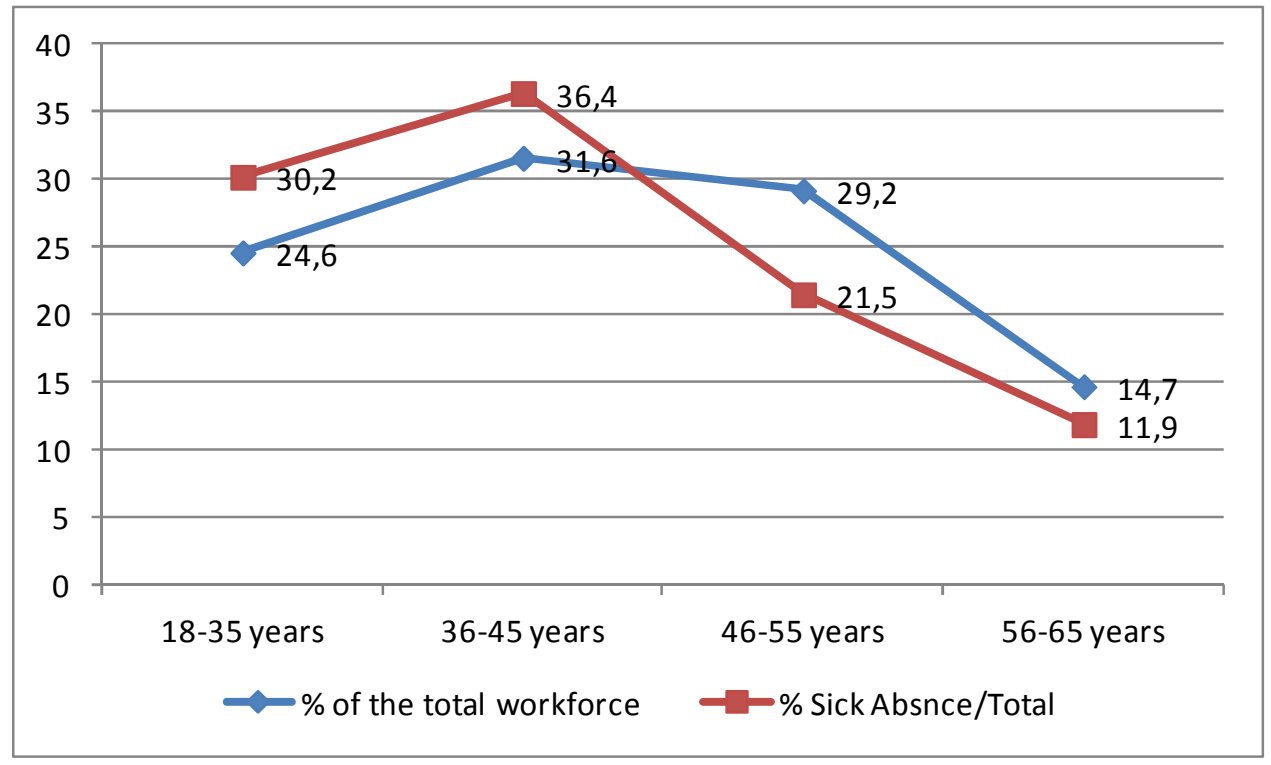

Source: Data gathered from the company.

Figure 5: Satisfacction and absenteeism in different business units of Fagor Electrodomésticos

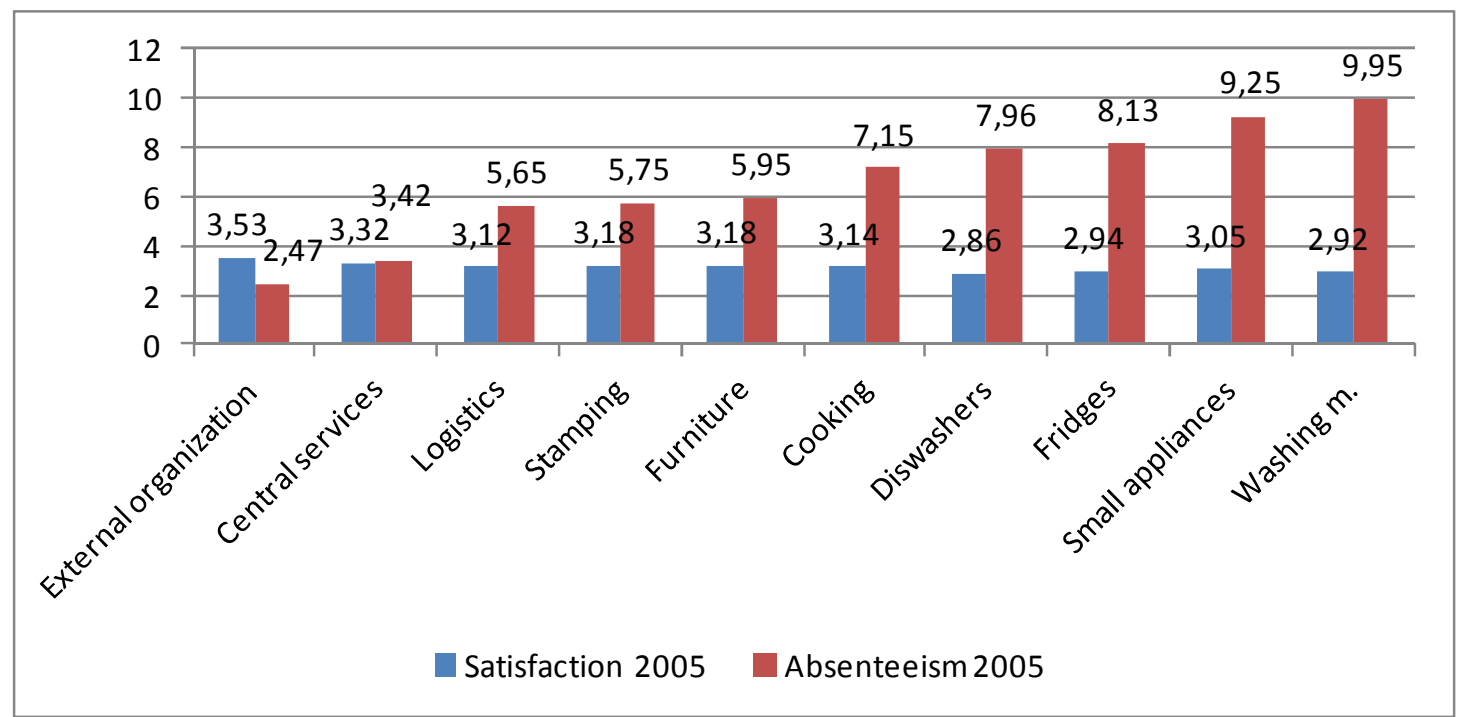

Source: Data gathered from the company. 
Figure 6: Global satisfacton Direct labor/Indirect Labor \& Members/non members 2003-2008

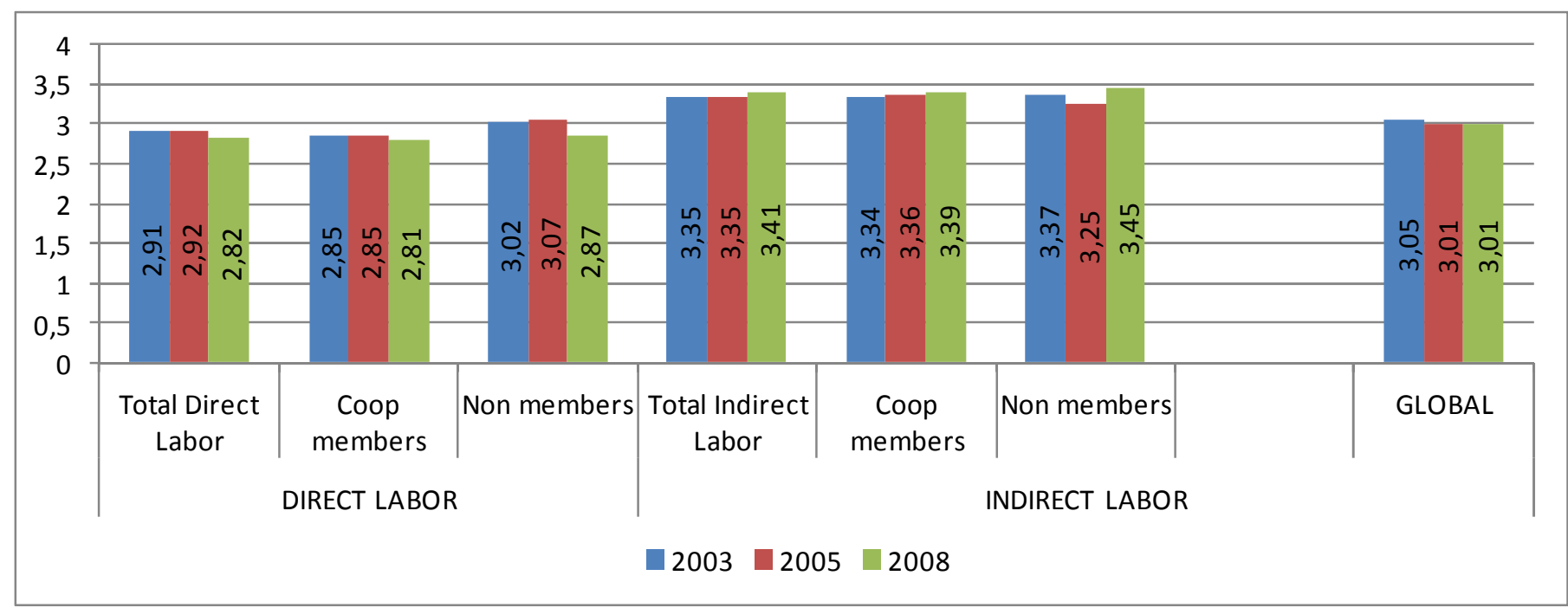

Source: Data gathered from the company. 
Table 1: Evolution of different employment models in Fagor Electrodomésticos (2000-2011).

\begin{tabular}{lrrrrrrrrrr}
\hline & 2003 & 2004 & 2005 & 2006 & 2007 & 2008 & 2009 & 2010 & 2011 & 2012 \\
\hline $\begin{array}{l}\text { Cooperative } \\
\text { working members }\end{array}$ & 3,067 & 3,520 & 3,424 & 3,393 & 3,082 & 2,718 & 2,474 & 2,325 & 2,219 & 2,067 \\
$\begin{array}{l}\text { Total employment } \\
\begin{array}{l}\text { of cooperative } \\
\text { working members }\end{array}\end{array}$ & 5,917 & 5,835 & 10,163 & 10,543 & 10,067 & 9,861 & 8,405 & 8,260 & 6,641 & 5,673 \\
\hline
\end{tabular}

Source: Authors' analysis based on Annual Reports of Fagor (2003-2012). 
Table 2: Satisfaction of cooperative members depending on age, tenure, training, salary index and professional group in the 2003 satisfaction survey

\begin{tabular}{|c|c|c|c|c|c|c|c|c|c|c|c|c|c|}
\hline & & 1 & 2 & 3 & 4 & 5 & 6 & 7 & 8 & 9 & 10 & 11 & Global \\
\hline \multirow{4}{*}{ AGE } & $<30$ & 2,8 & 2,7 & 2,8 & 3,1 & 2,9 & 2,8 & 3,1 & 2,9 & 3,3 & 3,4 & 3,4 & 2,94 \\
\hline & $31-40$ & 2,8 & 2,5 & 2,8 & 3 & 2,8 & 2,8 & 3 & 2,9 & 3,4 & 3,5 & 3,6 & 2,97 \\
\hline & 41-50 & 3 & 2,5 & 2,8 & 3,1 & 3 & 2,9 & 3 & 3 & 3,4 & 3,5 & 3,6 & 3,04 \\
\hline & $>50$ & 3,1 & 2,5 & 2,9 & 3,2 & 3 & 3 & 3,2 & $\overline{3,1}$ & 3,5 & 3,6 & $\overline{3,6}$ & 3,13 \\
\hline \multirow{4}{*}{ TENURE } & 5 or less & 2,8 & 2,7 & 2,8 & 3,1 & 2,9 & 2,8 & 3,1 & 2,9 & 3,3 & 3,4 & 3,4 & 2,96 \\
\hline & $6-15$ & 3 & 2,5 & 2,9 & 3,1 & 2,9 & 2,9 & 3,1 & 3 & 3,5 & 3,6 & 3,6 & 3,04 \\
\hline & $16-25$ & 2,9 & 2,4 & 2,8 & 3,1 & 3 & 2,9 & 3 & 3,1 & 3,5 & 3,5 & 3,6 & 3,04 \\
\hline & more than 25 & 3 & 2,5 & 2,9 & 3,1 & 3 & 2,9 & 3,1 & 3,1 & 3,5 & 3,6 & 3,6 & 3,06 \\
\hline \multirow{4}{*}{ TRAINING } & Primary & 2,9 & 2,6 & 2,8 & 3 & 2,9 & 2,9 & 3 & 3 & 3,3 & 3,5 & 3,4 & 2,98 \\
\hline & Mid level Vocat. Train & 2,9 & 2,6 & 2,7 & 3,1 & 2,9 & 2,9 & 3,1 & 2,9 & 3,4 & 3,5 & 3,5 & 3,01 \\
\hline & Superior Vocat. Train & 2,9 & 2,5 & 2,8 & 3,1 & 2,9 & 2,8 & 3,1 & 2,9 & 3,5 & 3,5 & 3,5 & 2,98 \\
\hline & University & 3,1 & 2,8 & 3 & 3,3 & 3,1 & 3 & 3,3 & 3,2 & 3,5 & 3,6 & 3,7 & 3,16 \\
\hline \multirow{5}{*}{ SALARY INDEX } & $1-1.35$ & 2,8 & 2,6 & 2,7 & 3 & 2,8 & 2,8 & 3 & 2,8 & 3,3 & 3,4 & 3,4 & 2,9 \\
\hline & $1.36-1.6$ & 3 & 2,4 & 2,9 & 3,2 & 2,9 & 2,9 & 3,1 & 3,1 & 3,5 & 3,6 & 3,6 & 3,08 \\
\hline & $1.61-2$ & 3,2 & 2,6 & 3,1 & 3,3 & 3,1 & 3,2 & 3,3 & 3,3 & 3,6 & 3,8 & 3,8 & 3,27 \\
\hline & 2.01-2.4 & 3,4 & 2,7 & 3,3 & 3,4 & 3,3 & 3,2 & 3,5 & 3,4 & 3,6 & 3,9 & 3,8 & 3,4 \\
\hline & $>2.41$ & 3,6 & 2,9 & 3,7 & 3,8 & 3,6 & 3,6 & 3,6 & 3,7 & 3,8 & 4 & 4 & 3,67 \\
\hline \multirow{3}{*}{ PROF. GROUP } & Direct labor & 2,8 & 2,6 & 2,7 & 3 & 2,8 & 2,8 & 3 & 2,8 & 3,3 & 3,4 & 3,4 & 2,91 \\
\hline & Sellers, technicians, a & 3,2 & 2,6 & 3,1 & 3,3 & 3,1 & 3,1 & 3,4 & 3,3 & 3,6 & 3,8 & 3,7 & 3,26 \\
\hline & Managers \& supervis & 3,5 & 2,8 & 3,6 & 3,7 & 3,5 & 3,5 & 3,5 & 3,6 & 3,8 & 4 & 4 & 3,57 \\
\hline
\end{tabular}

Source: Data gathered from the company. (1.- Working conditions; 2.- Economic reward; 3.- Professional growth and training; 4.- Organiztion of work; 5.- Information-communication; 6.- Participation; 7.- Working environment; 8.- Management and supervision; 9.- Strategies, goals and future of the organization; 10.Identification with the cooperative; 11.- Corporate values; 12.- Average satisfaction) 